\title{
La responsabilidad social y pedagógica de la evaluación de los aprendizajes
}

\author{
Alicia Wigdorovitz de Camilloni
}

Palabras clave. eevaluación de aprendizajes .

evaluación informativa formativa y performativa . usos internos y externos $\cdot$ responsabilidad social y pedagógica

Resumen. Se presentan, inscriptas en el marco de una definición amplia de la evaluación de los aprendizajes, sus distintas funciones (informativa, formativa y performativa), su importancia, sus alcances y sus requerimientos, en particular en lo que se refiere a sus usos internos y externos, de los que se derivan acciones que tienen consecuencias sociales y pedagógicas que ponen en juego cuestiones de índole moral para docentes, autoridades y decisores en materia de políticas educativas.
Keywords. learning assessment $\cdot$ informative assessment - formative assessment $\cdot$ performative assessment · internal and external uses of learning assessment functions · pedagogical and social responsibility

Abstract. We present the different functions (informative, formative, and performative) of learning assessment, within the context of its broad definition. We also discuss those function's relevance, scope, and requirements, referring in particular to their internal and external uses. Such uses lead to actions that have social and pedagogical consequences, which bring moral issues into play for educational policy teachers, authorities, and decision makers. 